\title{
Strategic positioning in banking industry: Evidence from banking industry
}

\author{
Hedieh Mashoof* and Fataneh Alizadeh Meshkani
}

Department of Management and Accounting, South Tehran Branch, Islamic Azad University, Tehran, Iran

\begin{tabular}{|c|c|}
\hline CHRONICLE & A B S T R A C T \\
\hline $\begin{array}{l}\text { Article history: } \\
\text { Received January } 20,2014 \\
\text { Accepted } 5 \text { July } 2014 \\
\text { Available online } \\
\text { July } 102014 \\
\text { Keywords: } \\
\text { Perceptual Map } \\
\text { Banking industry } \\
\text { Strategic positioning } \\
\text { Bank Melli Iran }\end{array}$ & $\begin{array}{l}\text { Strategic positioning has always been a key tool for managers to analyze the position of the } \\
\text { firm in different attributes in comparison with competitors. With regard to fierce competition in } \\
\text { banking industry, the aim of this study is to analyze the position of Bank Melli Iran with } 5 \\
\text { public and private rivals in } 6 \text { attributes. The sample of this study was } 387 \text { Bank Melli Iran } \\
\text { customers. The results of this study were in } 14 \text { perceptual maps in which the positions of Bank } \\
\text { Melli Iran attributes have been shown compared with bank's key competitors. The results } \\
\text { showed that Bank Melli Iran had strong position and came to the first place in attributes like } \\
\text { price, physical equipment and location and security. Moreover, Bank Melli Iran has to improve } \\
\text { its position in attributes with no better position. }\end{array}$ \\
\hline
\end{tabular}

\section{Introduction}

Banking industry has always been a scene of fierce competition. In Iran, mostly after establishment of several private banks, the competition has been increased during the past few years. According to statistics, there are 21 private banks in Iran, which are rivals of eight governmental banks. Bank Melli Iran as one of the oldest governmental banks has more than 45000 employees. According to banker website statistics in the latest released ranking of banks, Bank Melli Iran has the first place regarding the amount of assets, which is almost 80 billion dollar.

Considering the abovementioned statistics, Bank Melli Iran has enough internal strength to compete in this industry but internal strength does not show the whole picture since strategic analysis is always about internal strength and weaknesses in comparison with opportunities and threats in presence of competitors. Therefore, a comprehensive analysis of situation of this bank in the banking industry and among competitors is needed to show the status of the bank in this industry.

Regarding the internal literature, strategic analysis in banking industry is limited to strength, weakness, opportunity and threats (SWOT) analysis and strategic planning, there are few studies

*Corresponding author. Tel: +989127009197

E-mail addresses: hediehmas@gmail.com (H. Mashoof) 
which are about strategic positioning. Therefore, there is a gap in internal literature and strategic positioning and particularly perceptual map. The aim of this study is to analyze the position of Bank Melli Iran among its main competitors. In the other words, the main purpose of this study is to detect the position of Bank Melli Iran in the mind of its customers regarding the main dimensions of strategic performance.

The remaining of this study is structured as following. At the next section, literature review is presented and section 3 presents the methodology used for performing this study. After presenting the methodology, analysis of the data will be followed and findings will be the next section showing the results of the data analysis. Finally, conclusion section is the final section of this article in which we will present managerial implications and directions for future studies.

\section{Literature review}

\subsection{Banking industry in Iran}

There are 8 state-owned banks including three commercial, five specialized in Iran, supplemented by 21 private commercial banks. The Central Bank of the Islamic Republic of Iran (CBI) is responsible for the design and the implementation of monetary and credit policies concerning the general economic policy of the country. Iranian state-owned banks are among the largest Islamic banks in the world, comprising seven out of the top 10 Asian Banker Research, 2008. The state-owned banks have also been the most successful in acquiring domestic market share since the private banks joined the market after 2001. During the last decade, the industry has undergone extensive changes due to factors such as increased government regulation and technological advances. Changes in policy have affected both state-owned and private banks. Generally, it appears that state-owned banks have been more noticeably affected by the Iranian government's regulatory initiatives launched in 2005, which obliged all banks to markedly reduce deposit and loan interest rates. The government also imposed different interest rates and conditions on state-owned versus private banks. For instance, state-owned banks were obliged to assign higher priority in their lending operations to areas such as advanced technology projects, small and medium-sized enterprises and housing projects for low-income earners. As a result, state-owned banks raised their loans and advances to the private sector by 30 percent and 29 percent in 2006 and 2007, respectively.

\subsection{Positioning}

Kotler (2003) defined positioning as the act of designing a firm's offering and image to occupy a distinctive place in the mind of the target market with concomitant effect of creating a customerfocused value proposition that would facilitate patronage. Ries and Trout (1986) described positioning as a collection of creative activities, which manipulates the consumers' mind in favor of the brand. They emphasized that positioning starts with a product and ends up creating a space and occupying it in the consumers' minds. They argued that a well-known brand only holds a distinctive position in consumer's mind which may be difficult for the competitors to claim, and that this position would only be maintained with well-articulated strategies concerning product, price, place, and promotion. Treacy and Wiersema (1994) described positioning as a collection of activities that instills value disciplines such as product leadership, operational excellence or customer-intimacy. This is based on the notion that in every market, there is a mix of three types of customers; some that prefer firm that is technologically inclined (product Leadership); others that favor a highly reliable performance (operational excellence) and still, others want high responsiveness in meeting their individual needs (customer intimacy). They argued that no firm was best in any two of these ways as each value disciplines requires different managerial mind-sets and investments that often conflict.

Treacy and Wiersema (1994) thus proposed that for a business to be successful in positioning its brand there are four major things to accomplish: first it must become best at one of the three value disciplines, second, it must also achieve adequate performance level in the other two disciplines, 
third, it must keep improving its superior position in the chosen discipline so as not to lose its position to competing firms and finally, it must not lose sight of the relevance of the other two disciplines as competing firms raise customers' expectations.

Sengupta (1997) detected positioning as an act of identifying a vacant space in the consumers' mind space and occupying it for periods that varies according to the quality and quantity of marketing efforts behind the brand. He views it as a deliberate attempt to create a perception for a brand in the prospects' mind so that it stands apart from competing brands and approximates much more closely to what the consumers want. It is a matter of finding a strong position in that mind and sit on it, which means the same brand, in the same pack, with the same formulations can seek different positions in the consumer's mind space. He argues that positioning is less of what we do to the product and more of what we do to the customer's perception of the product. He further emphasizes that positioning is thus the fountain head decision, from which flows all other marketing and advertising decisions and that it provides the direction and thrust to marketing and advertising planning and also fuse them and the marketing mix into a cohesive whole. He finally submits that the position of a brand is its perception among target consumers based on its functional attributes and benefits, as well as on the non-functional or emotional associations it has acquired from its advertising. The colouration of these different perceptions by consumers' own attitudes, beliefs and experience, make different consumers segments to perceive the brand differently, and secondly the brand's position is perceived in relation to competitive brands. This position concurs with the opinions of Perreault Jr. et al (2009) and Kerin et al (2010). However, Etzel et al. (2007) considered it as fitting the product to the segment where product performances and appeals most correspond. It infers that there is a point where the appeal of a product corresponds with its performance. That is, the point where the quality that makes the product attractive or interesting must equate to its performance, such that, the customers are not disappointed, and thus fulfilling the unspoken promises made to the customers. Etzel et al. (2007) recognized this point as the positioning of the brand.

This sounds vague and divergent from earlier thoughts of image creation and mind space as postulated by Kolter (2003), Ries and Trout (1982) and Segupta (1997) but tend to align with Treacy and Wiersena (1994)'s idea of product leadership. Smith and Lusch (1976) defined positioning as a brand's objective or (functional) attributes in relation to other brands; it is a characteristic of a physical product and its functional features. They see 'position' as brand's subjective or perceived image, which belongs not to the product, but rather, it is a mental picture, which could differ from the true physical picture of the brand. The definition emphasizes attributes analysis and estimation that positions the brand in the mind of the consumers, which makes the definition to align with the views of Kotler (2003) and Segupta (1997) but specific issues pertaining to product leadership, operational excellence or customer intimacy are not mentioned but may be inferred.

Rosser Reeves as cited by Sacco (1986) sees positioning as the art of selecting, out of a number of unique selling propositions, the one, which will get you maximum sales. This definition looks at positioning superficially, it lacks the depth that the earlier definitions carry. This is because positioning is more than framing a set of words, the definition also plays down on the opinion of Crawford (1987) who believe that positioning is meant to drive the entire marketing program of the organization, which aligns with Aaker (1984)'s view that product positioning is so central and critical that it should be considered at the level of a mission statement because it comes to represent the essence of a business.

From the foregoing, it is obvious that what 'positioning' represents seems to be ambiguous as the meaning varies from one researcher to another. However, positioning from the literature reviewed could thus be said to be, the perception of a brand that the consumers hold which makes it to occupy a space in the mind of the consumer as a brand leader, or operationally excellent brand, or customer intimated brand. 


\subsection{Prior research}

\subsubsection{Internal studies}

In recent years, there have been different studies which have the most similarity with our study and will be presented here:

- In an Iranian study, the priorities of competition has been identified which were used for determining the strategy of the firm. The sample of the study was 85 industrial firms and the products have been extracted from questionnaire which has 5 following factors: 1- quality of the designed product. 2- Flexibility of the volume of the product. 3- Delivery time. 4- Cost. 5Flexibility.

- Some other people investigated the position of a product in the home appliance industry. They first chose 18 variables as the effective variables in the eye of the potential customers and with use of factor analysis extracted the effective factors in the eye of the customers having detrimental effect on the position of the products which were quality of the product, price, after sale effect, advertising and distribution.

- Others conducted a research in the realm of strategic positioning and identification of resources for reaching competitive advantage, the case study of this research was banking industry. Seven factors were identified which were employees interaction with customers, responsiveness, profit, agility in work, quality of service, location of the branch, quality of delivery service. Mentioned factors were analyzed by t test and results showed that human factor has a very important factor in success of banks.

- Another study performed a study about strategic positioning in Iran banks for electronic services. The sample of this study was customers of 8 banks in Alborz province which were using electronic services. Regarding the importance of the factor in choosing the bank, finally 583 customers were chosen for distributing questionnaire among them. And after collecting and analyzing the data perceptual maps were depicted.

In the research of Hassan et al., (2012), segmentation and strategic positioning has been investigated for brand. In this study, researchers concluded that there were 4 main types of strategic positioning for brand as follows,

1- Developing the position of the market for brand by use of identification and choosing customers who give the same response to a brand,

2- Choosing different parts in different countries by the same attraction for brand,

3- Harmony of the brand with sections basis on foundations of locals,

4- Concentration on different parts with unique brands.

Tinnilä (2012) investigated the changes in bank services particularly mass services. Blankson and Crowford (2011) investigated strategic positioning of retail service firms in Texas and reported that the prominent factors for positioning was brand name, services, value for money, reliability, attractiveness.

\section{Methodology}

\subsection{Sample}

The population of this study included all the customers of Bank Melli Iran in city of Tehran. The sample had been chosen by cluster technique in which city of Tehran has been divided to 5 sections and in each section, two branches were chosen randomly and questionnaire has been distributed in the chosen branches. Since the population of this research was infinite, the number of sample has been chosen by Cokran formula which is 384 and after distribution of the questionnaire, 387 usable questionnaires have been collected for analysis. Demographic of the sample is given in Fig. 1. 


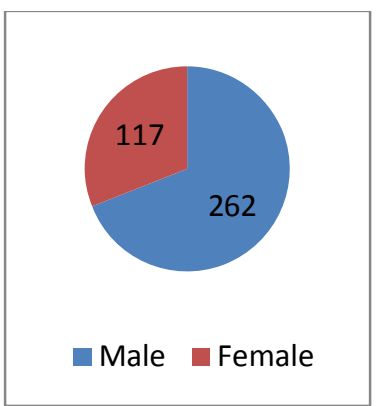

Gender

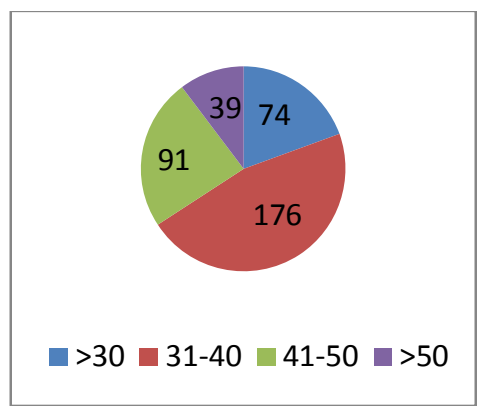

Age

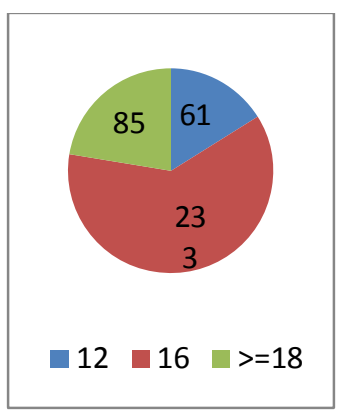

Years of education

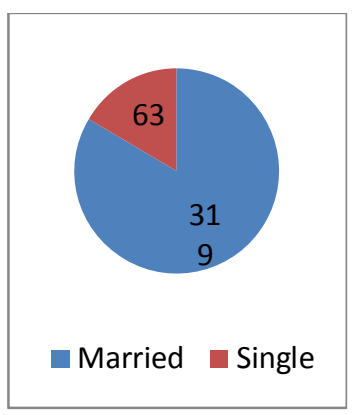

Marital status

Fig. 1. Personal characteristics of the participants

The measures used in this research were extracted by use of relevant literature and prior works accomplished in this realm. By studying relevant works, 6 dimensions has been chosen and questions of each dimension with reliability of them after calculating the Cronbach alpha is given in Table 1 .

Table 1

Dimensions and questions

\begin{tabular}{|c|c|c|c|}
\hline Dimensions & Questions & Dimensions & Questions \\
\hline \multirow{3}{*}{ Services } & Quality of services & \multirow{4}{*}{$\begin{array}{l}\text { Interaction of employees } \\
\text { with customers }\end{array}$} & Type of interaction \\
\hline & Variety of services & & Appearance of employees \\
\hline & New services & & Intimacy \\
\hline \multirow[t]{3}{*}{ security } & Security of transactions & & Responsibility \\
\hline & Reliability of transactions & \multirow[t]{3}{*}{ Advertising and promotion } & Information services \\
\hline & Precision in services & & Other promotional activities \\
\hline \multirow[t]{4}{*}{ price } & Profit of the accounts & & Reputation of the bank \\
\hline & Cost of services & \multirow{3}{*}{$\begin{array}{l}\text { Physical equipment and } \\
\text { location of the branch }\end{array}$} & Ambience and Internal decoration \\
\hline & & & Internal coloration \\
\hline & & & External view \\
\hline
\end{tabular}

Table 2

Reliability of the questionnaire

\begin{tabular}{llll}
\hline Factor & Cronbach alpha & Factor & Cronbach alpha \\
\hline Services & 84 & Employee interaction with customers & 84.3 \\
Security & 83.3 & Advertising and promotion & 80 \\
Physical equipment and location of the branch & 82.8 & Total & 88.5 \\
Price & 76.1 & & \\
\hline
\end{tabular}

In this paper, we test the difference between different dimensions by use of Mann-Whitney test and then we will present perceptual maps for different attributes among 6 banks. Table 3 shows the results of Mann-Whitney test.

Table 3

Mann-Whitney test for services

\begin{tabular}{llll}
\hline Banks & Z & Significance & Situation \\
\hline Melli and Mellat & -1.652 & 0.089 & Not significant \\
Melli and Pasargad & -2.431 & 0.046 & Significant (Pasargad better than Melli) \\
Melli and Parsian & -1.681 & 0.081 & Not significant \\
Melli and Saderat & -2.881 & 0.032 & Significant (Melli better than Saderat) \\
\hline
\end{tabular}

As it is shown in Table 3, there is a significant difference between Pasargad and Melli banks and Melli and Saderat banks in services dimension.

\section{Table 4}

Mann-Whitney test for security

\begin{tabular}{llll}
\hline Banks & Z & Significance & Situation \\
\hline Melli and Mellat & -2.591 & 0.042 & Significant (Melli better than Mellat) \\
Melli and Pasargad & -2.792 & 0.038 & Significant (Melli better than Pasargad) \\
Melli and Parsian & -4.973 & 0.012 & Significant (Melli better than Parsian) \\
Melli and Saderat & -5.639 & 0.000 & Significant (Melli better than Saderat) \\
\hline
\end{tabular}


As shown in Table 4, Melli bank has a better situation among all the competitors and all the differences are significant.

Table 5

Mann-Whitney test for physical equipment

\begin{tabular}{lccc}
\hline Banks & Z & Significance & Situation \\
\hline Melli and Mellat & -2.572 & 0.044 & Significant (Melli better than Mellat) \\
Melli and Pasargad & -2.839 & 0.031 & Significant (Melli better than Pasargad) \\
Melli and Parsian & -5.023 & 0.000 & Significant (Melli better than Parsian) \\
Melli and Saderat & -4.202 & 0.016 & Significant (Melli better than Saderat) \\
\hline
\end{tabular}

The results of Table 6 show that Melli bank had a better situation among all the competitors and all the differences are significant.

Table 6

Mann-Whitney test for price

\begin{tabular}{lccc}
\hline Banks & Z & Significance & Situation \\
\hline Melli and Mellat & -4.941 & 0.000 & Significant (Melli better than Mellat) \\
Melli and Pasargad & -6.042 & 0.000 & Significant (Melli better than Pasargad) \\
Melli and Parsian & -5.184 & 0.000 & Significant (Melli better than Parsian) \\
Melli and Saderat & -2.582 & 0.043 & Significant (Melli better than Saderat) \\
\hline
\end{tabular}

The results of Table 6 shows that Melli bank has a better situation among all the competitors and all the differences are significant.

Table 7

Mann-Whitney test for employee interaction

\begin{tabular}{lccc}
\hline Banks & Z & Significance & Situation \\
\hline Melli and Mellat & -4.941 & 0.000 & Significant (Melli better than Mellat) \\
Melli and Pasargad & -6.042 & 0.000 & Significant (Melli better than Pasargad) \\
Melli and Parsian & -5.184 & 0.000 & Significant (Melli better than Parsian) \\
Melli and Saderat & -2.582 & 0.043 & Significant (Melli better than Saderat) \\
\hline
\end{tabular}

As shown in Table 7, Melli bank's situation is not good in this dimension and all other banks have better situations.

Table 8

Mann-Whitney test for promotion

\begin{tabular}{llll}
\hline Banks & $\mathrm{Z}$ & Significance & Situation \\
\hline Melli and Mellat & -4.103 & 0.019 & Significant (Melli better than Mellat) \\
Melli and Pasargad & -1.419 & 0.092 & Not Significant \\
Melli and Parsian & -3.982 & 0.024 & Significant (Melli better than Parsian) \\
Melli and Saderat & -2.639 & 0.04 & Significant (Melli better than Saderat) \\
\hline
\end{tabular}

According to the results of Table 8, except the difference between Melli and Pasargad, all the differences are significant. Since we have investigated six attributes among different banks, we depict all the extracted perceptual maps from them. Therefore, 15 perceptual maps will be depicted in this section and separately. Fig. 2 shows the results of the perceptual map for two factors of services and security. 


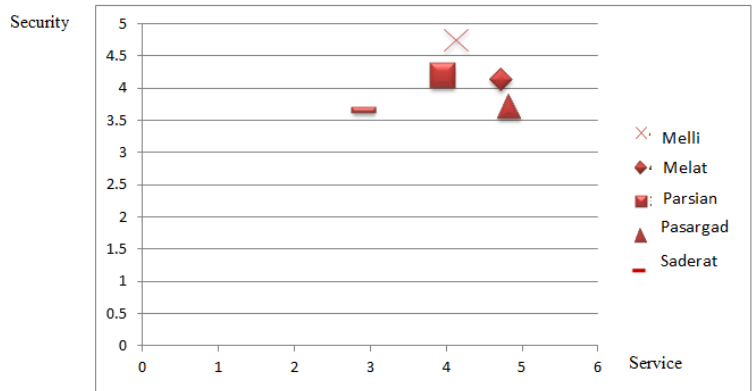

Security versus Service

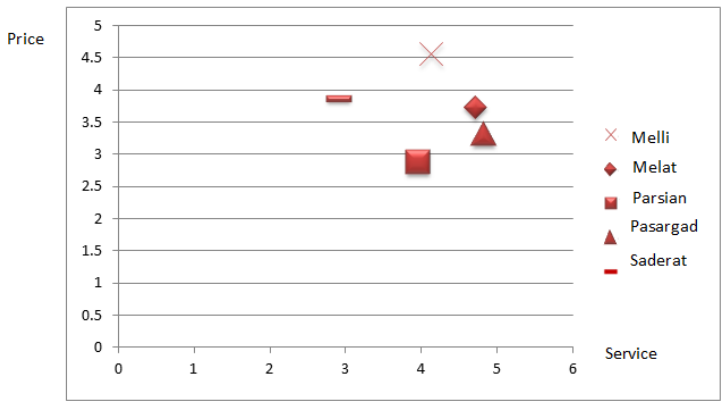

Price versus Service

Fig. 2. The results of Perceptual map for security and price versus service

As shown in Fig. 2, Bank Melli Iran has a better position in security dimension and Pasargad bank has better position in services dimension. In addition, in terms of services dimension, Parsian bank and in physical equipment dimension Melli and Melat banks are in the good position among competitors.

Employee interaction

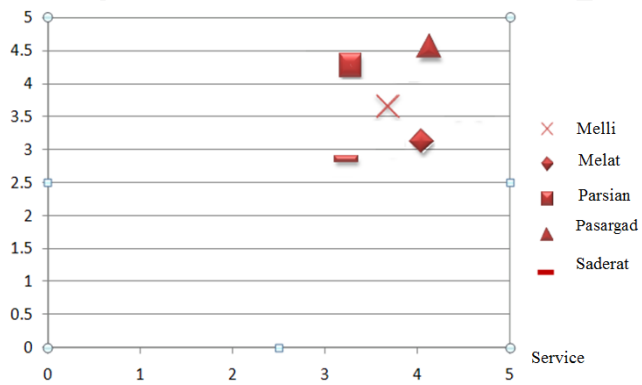

Employee interaction versus Service

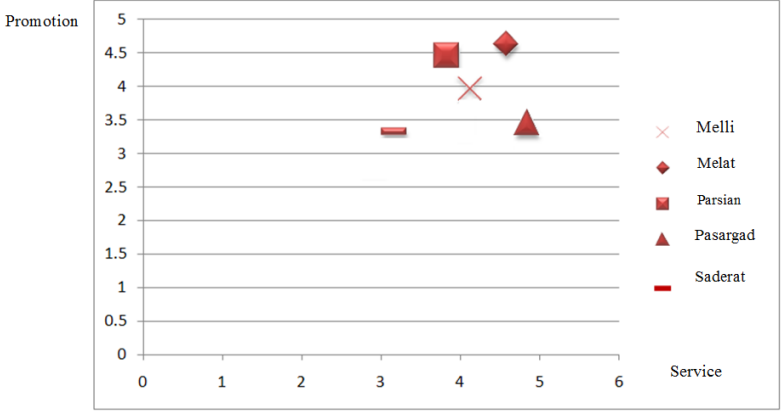

Promotion versus Service

Fig. 3. The results of perceptual map employee interaction and promotion versus service

According to the results of Fig. 3, employees' interaction for Pasargad and Parsian banks has better positions. In addition, Bank Melli Iran a better position among competitors in the mind of its customers in two dimensions of services and promotion.

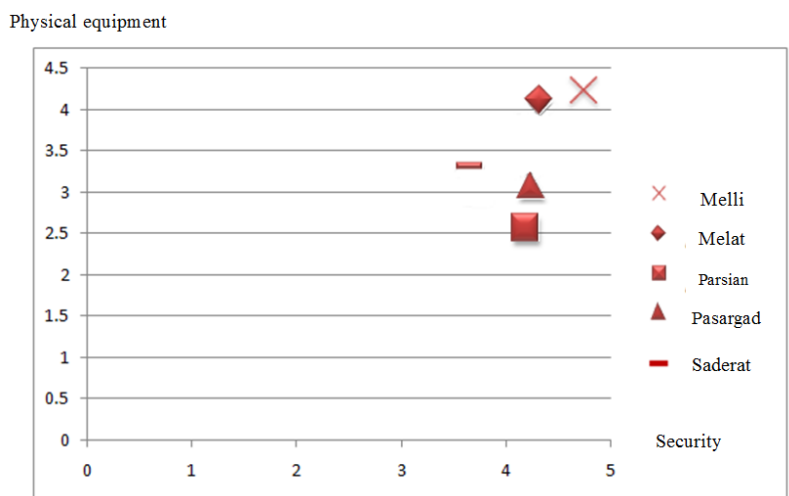

Physical equipment versus security

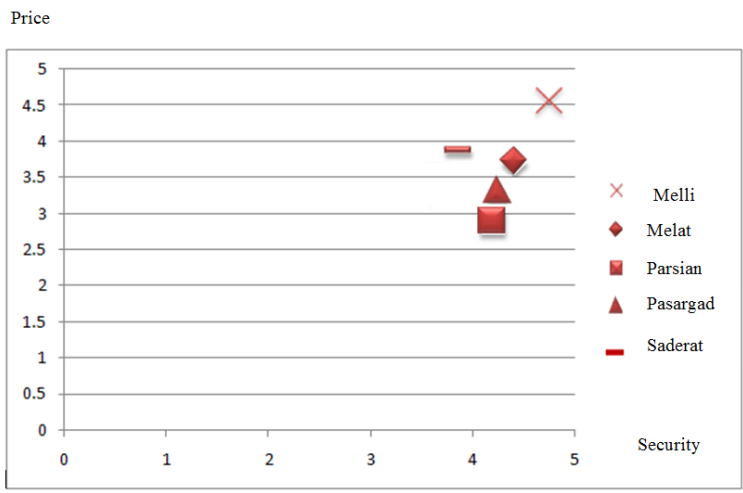

Price versus security

Fig. 4. The results of perceptual map for physical equipment versus security and price versus security

In terms of security versus physical equipment, Bank Melli Iran has a better position among competitors in the two analyzed dimensions. 
Employee interaction

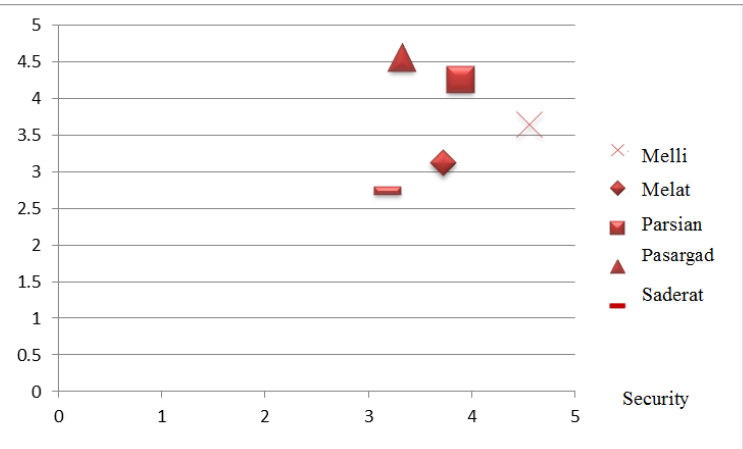

Employee interaction versus Security
Promotion

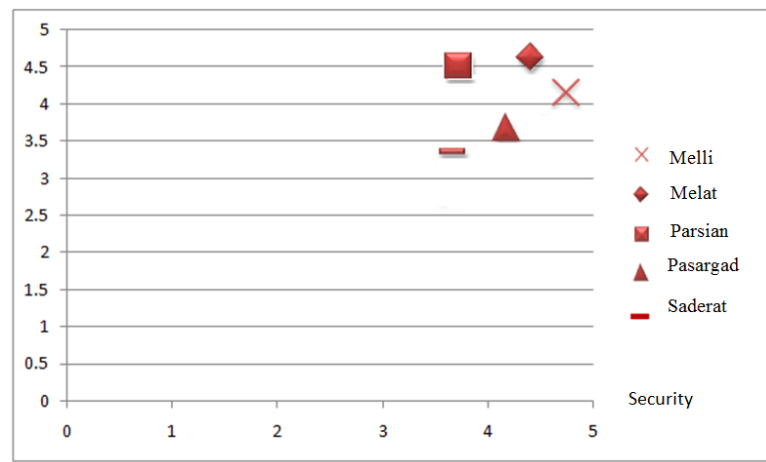

Promotion versus Security

Fig. 5. The results of perceptual map for physical equipment versus security and price versus security

According to Fig. 5, Pasargad bank is in better position in terms of employee interaction and Melat bank is in better position in terms of promotion.

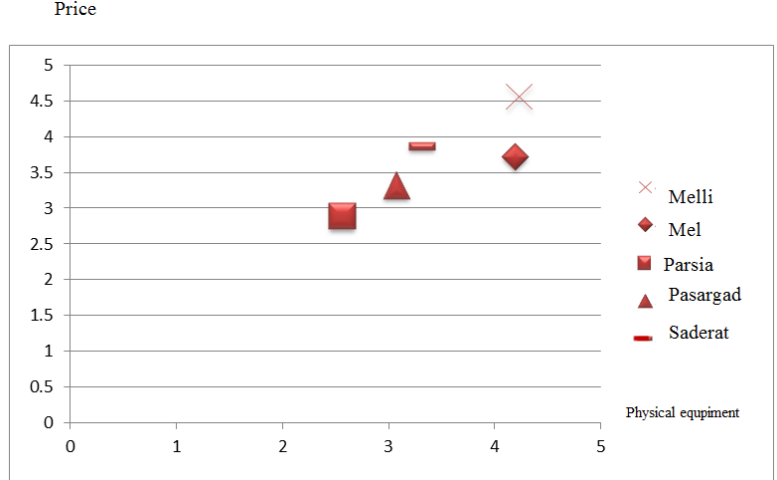

Price versus Physical equipment

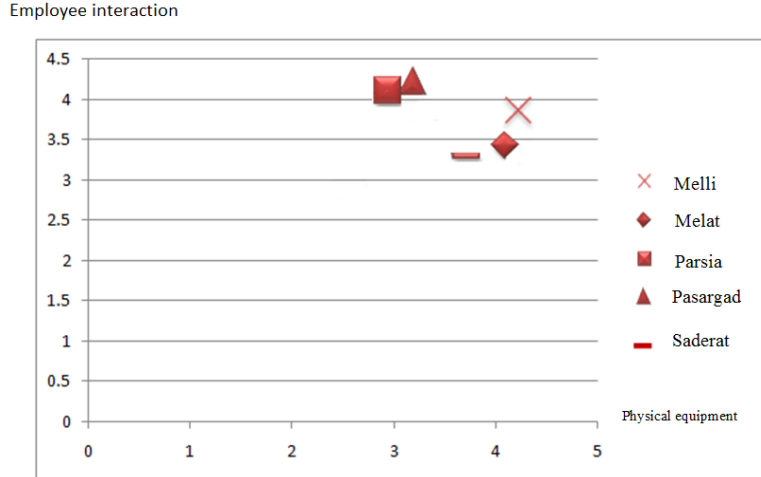

Employee interaction versus Physical equipment

Fig. 6. The results of perceptual map for price versus physical equipment and employee interaction versus physical equipment

According to Fig. 6, Melli bank is in better position in terms of price and Parargad bank is in better position in terms of employee interaction.

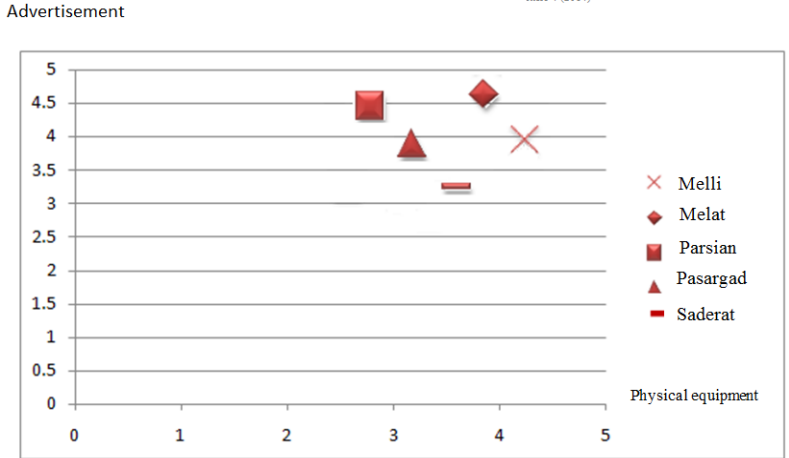

Advertisement versus Physical equipment

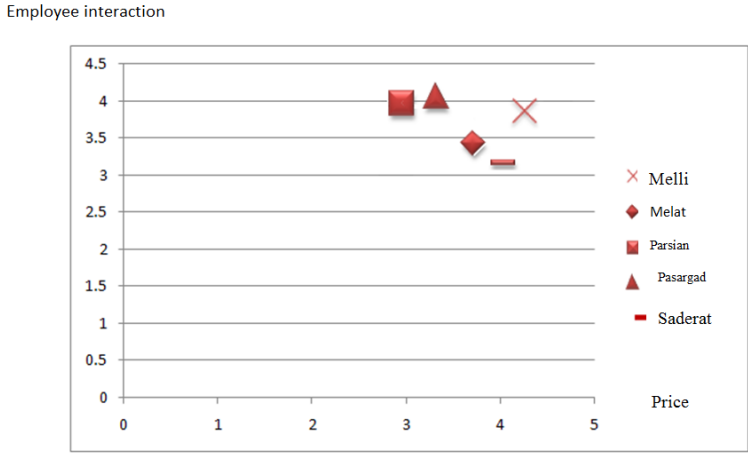

Employee interaction versus price

Fig. 7. The results of perceptual map for advertisement versus physical equipment and employee interaction versus price 
According to Fig. 7, Mellat bank is in better position in terms of physical equipment and Parargad bank is in better position in terms of price. Finally, in terms of comparing employee interaction versus promotion, our survey indicates that Bank melat is in better position.

\section{Results and discussion}

In this paper, we have presented an investigation on perceptual map analysis of an Iranian bank named Melli bank compared with some other competitors. The results of our survey have shown that Bank Melli Iran in this dimension maintained the third place among competitors and Pasargad bank was at the first place in this regard. This means that Bank Melli Iran should choose a proper strategy to boost its existing status. Regarding the security as we expected, Bank Melli Iran was in the first place among all the competitors. This is evidence for high position of Melli bank's security in customers' mind. Physical equipment was the next dimension we analyzed versus location of the branch. In this regard, Bank Melli Iran position was better than the competitors and there was a significant difference between its position and position of its customers. Regarding the price dimension, Melli's bank position was much better than its customers due to low commission rates but the dimension like employees' interaction was not in favor of Bank Melli Iran. Finally, in terms of promotion dimension, Bank Melli Iran was in the third place, which is after Melat and Parsian banks. In our survey, we may recommend that managers of Bank Melli Iran use benchmarking and investigate the methods used by key banks in the world. In terms of security dimension, it is recommended that managers follow existing procedures to sustain and improve present circumstances. In terms of physical equipment and location of the branches, due to high number of Bank Melli Iran branches in Iran, we may expect a good position of the bank and believe the best strategy for the bank in this regard is to keep the current position. In terms of the price dimension, since the commission of the Bank Melli Iran is far less than its competitors, the bank has the first position in this dimension. Although low commission will bring less profit but it will gain customers satisfaction and loyalty. Therefore, the best recommendation here for banks' managers is to sustain the current position by holding the existing commission and prices. In terms of employees' interaction dimension, Bank Melli Iran position was not as good as other dimensions and regarding the importance of this dimension, this factor should be improved. Therefore, we recommend managers of the bank to conduct training programs for employees and familiarize them with the newest technique for encountering customers. Finally, regarding the promotion and advertising dimension, Bank Melli Iran should revise its activities in this dimension. Using television advertising, in branch advertising, selecting good media, supporting favorite activities of the people like sports, movies, theater was among the activities which other banks has used most of them and Bank Melli Iran should design a best selection of the mentioned techniques.

\section{References}

Anderson, W. T., Cox, E. P., \& Fulcher, D. G. (1976). Bank selection decisions and market segmentation. The Journal of Marketing, 40(1), 40-45.

Bilgin, Z., \& Yavas, U. (1995). Marketing of consumer credit services in a developing country: a status report. International Journal of Bank Marketing,13(5), 31-36.

Blankson, C., \& Crawford, J. C. (2012). Impact of positioning strategies on service firm performance. Journal of Business research, 65(3), 311-316.

Devlin, J., \& Ennew, C. T. (1997). Understanding competitive advantage in retail financial services. International Journal of Bank Marketing, 15(3), 73-82.

Hassan, S. S., \& Craft, S. (2012). Examining world market segmentation and brand positioning strategies. Journal of Consumer Marketing, 29(5), 344-356.

Kibritçioğlu, A. (2005). Banking sector crises and related new regulations in Turkey. Economia Exterior, 32.

Knox, S. (2004). Positioning and branding your organisation. Journal of Product \& Brand Management, 13(2), 105-115. 
Kotler, P. (1994). Marketing Management - Analysis, Planning, Implementation, and Control, Prentice-Hall, Englewood Cliffs, NJ.

Laroche, M., Rosenblatt, J. A., \& Manning, T. (1986). Services used and factors considered important in selecting a bank: an investigation across diverse demographic segments. International Journal of Bank Marketing, 4(1), 35-55.

Malhotra, N. K. (2008). Marketing Research: An Applied Orientation, 5/E. Pearson Education India.

Martenson, R. (1985). Consumer choice criteria in retail bank selection.International Journal of Bank Marketing, 3(2), 64-74.

Minhas, R. S., \& Jacobs, E. M. (1996). Benefit segmentation by factor analysis: an improved method of targeting customers for financial services. International Journal of Bank Marketing, 14(3), 313.

Nunnally, J.C. (1978). Psychometric Theory. $2^{\text {nd }}$ ed., McGraw-Hill, New York, NY.

Parasuraman, A., Zeithaml, V. A., \& Berry, L. L. (1985). A conceptual model of service quality and its implications for future research. the Journal of Marketing, 49(4), 41-50.

Parasuraman, A., Zeithaml, V., \& Berry, L. (2002). SERVQUAL: a multiple-item scale for measuring consumer perceptions of service quality. Retailing: critical concepts, 64(1), 140.

Lawtor, L., \& Sinkula, J. M. (1988). Bank Characteristics and Consumer Bank Choice: How Important Are Importance Measures?. Journal of Professional Services Marketing, 3(3-4), 131141.

Ta, H. P., \& Har, K. Y. (2000). A study of bank selection decisions in Singapore using the analytical hierarchy process. International Journal of Bank Marketing,18(4), 170-180.

Taskin, F.D. (2009). The aftermath of banking crisis in an emerging economy: evidence from the 1994 and 2001 banking crises of Turkey. Journal of Money, Investment and Banking, 12, 37-41.

Tinnilä, M. (2012). Impact of future trends on banking services. Journal of Internet Banking and Commerce, 17(2), 1-15.

Yavas, U., Bilgin, Z., \& Shemwell, D. J. (1997). Service quality in the banking sector in an emerging economy: a consumer survey. international journal of bank marketing, 15(6), 217-223.

Ying, L.C., \& Chua, A. (1989). The analytic hierarchy process: survey of the method and its implication. Malaysian Management Review, 24(3), 55-67.

Young, M. R. (1999). Market structure analysis: a foundation for developing and assessing bank strategy. International Journal of Bank Marketing, 17(1), 20-25.

Zeithaml, V., Parasuraman, A., \& Berry, L. (1990). Delivering Quality Service - Balancing Customer Perceptions and Expectations. The Free Press, New York, NY.

Zineldin, M. (1993). Bank strategic planning process:" mission, swot analysis, and market segmentation". Univ., Företagsekonomiska institutionen.

Zineldin, M. (1995). Bank-company interactions and relationships: some empirical evidence. International Journal of Bank Marketing, 13(2), 30-40.

Zineldin, M. (1996). Bank strategic positioning and some determinants of bank selection. International Journal of Bank Marketing, 14(6), 12-22.

Zineldin, M. (2000). TRM. Studentliteratur, Lund.

Zineldin, M. (2002). Managing in the@ age: banking service quality and strategic positioning. Measuring Business Excellence, 6(4), 38-43. 